University of Nebraska - Lincoln

DigitalCommons@University of Nebraska - Lincoln

USDA National Wildlife Research Center - Staff

Publications

U.S. Department of Agriculture: Animal and Plant Health Inspection Service

August 2003

West Nile Virus: Emerging Threat to Public Health and Animal

Health

Robert G. McLean

USDA-APHIS-Wildlife Services

Follow this and additional works at: https://digitalcommons.unl.edu/icwdm_usdanwrc

Part of the Environmental Sciences Commons

McLean, Robert G., "West Nile Virus: Emerging Threat to Public Health and Animal Health" (2003). USDA National Wildlife Research Center - Staff Publications. 248.

https://digitalcommons.unl.edu/icwdm_usdanwrc/248

This Article is brought to you for free and open access by the U.S. Department of Agriculture: Animal and Plant Health Inspection Service at DigitalCommons@University of Nebraska - Lincoln. It has been accepted for inclusion in USDA National Wildlife Research Center - Staff Publications by an authorized administrator of DigitalCommons@University of Nebraska - Lincoln. 


\section{West Nile Virus: Emerging Threat to Public Health and Animal Health}

Robert G. McLean

West Nile virus (WNV) is in the genus Flavivirus, family Flaviviridae, and is closely related to other members of this genus: Japanese encephalitis virus in Southeast Asia, Murray Valley encephalitis virus in Australia, and St. Louis encephalitis (SLE) virus in North and South America. The principal vertebrate hosts for these arthropod-borne viruses (arboviruses) are wild birds, and the primary vectors are mosquitoes. Little clinical disease or mortality has been reported previously in wild birds from natural infection with these viruses, although significant morbidity and mortality has occurred in humans and domestic animals. West Nile virus (WNV) previously occurred throughout Africa, Middle East, Europe, and the western parts of Asia and was introduced into the United States in New York City ( ${ }^{\top} Y C$ ) in 1999. It is still unknown how WNV entered the US, but it quickly became established, causing a human epidemic of 62 cases and an epizootic in the regional bird population, mostly in American crows. The W.VV strain introduced was virulent for North American birds and caused significant mortality in crows and related species. This bird mortality was unusual for arboviruses but quickly became a useful sentinel for public health officials to detect the presence of WNV.

Multistate surveillance was established in 2000 in the Atlantic and Gulf coastal states by the Centers for Disease Control and Prevention (CDC) to track possible WNV expansion from the affected area in the northeast and was expanded nationwide in 2001. Components of the surveillance network included dead bird surveillance (virus testing of dead wild birds), monitoring serologic conversions in sentinel chickens, mosquito monitoring and testing, and enhanced passive veterinary and human surveillance. Advanced virus/antigen detection systems (polymerase chain reaction, PCR) provided rapid testing of birds and mosquitoes and aided in tracking the movement of the virus, and sensitive and specific serologic testing enabled the rapid detection and subsequent confirmation of human and equine cases. A national database system (ArboNET) was established and maintained by CDC to allow weekly reporting and updating of WNV surveillance information by all states involved in the surveillance, and maps, updated weekly, of the reported information were prepared by the US Geological Survey.

The surveillance detected the survival of the virus through the winter of 1999-2000 in the epicenter and its expansion to 12 states in 2000 . In $2001 \mathrm{WNV}$ reappeared early in the spring in a broader epicenter area in the northeastern states, as well as in a new virus focus, early in the season, in northern Florida, probably as a result of a successful introduction of virus there in the fall of 2000 by southward migratory birds that were likely infected in the northeast. The virus quickly spread throughout 27 eastern states and Ontario, Canada with a concomitant increase in human and equine cases, dead birds, and positive mosquitoes. It appears that the rapid geographical expansion of WNV in 2001 was aided by the seasonal movement of migratory birds, first north from Florida in the spring, introducing WNV to northem latitudes, including the mid-western states, and subsequently south along the Mississippi River in the fall, seeding the virus in southern states such as Louisiana. Millions of birds move along four major traditional migratory corridors, like the Mississippi Flyway, each season, between breeding grounds in the north and wintering areas in the south.

The dramatic expansion in WNV distribution and disease intensity in 2002 was unprecedented. Virus activity was detected early in the year in Louisiana, supporting the idea of the introduction of WNV by migratory birds in the fall of 2001, and one of the many human epidemics that occurred in the US in 2002 occurred in that state during the summer. The virus was subsequently detected early in the season in a number of previously affected locations in the eastern states and Canada. However, new foci of infection were soon detected in Texas, followed by states in the Great Plains and Rocky Mountain region, the central Canadian provinces, and finally, a total of 43 states, DC, and 5 provinces were affected. Virus activity became diffused across a large region of the North American continent and caused a more than 50 -fold increase in the number of human cases (58 to $>3,600$ ) and nearly 20 -fold increase in equine cases (738 to $>13,000$ ) in the L.S. as a consequence of similar increases in wild bird infections and mortality. Rapid dissemination of WNV by migratory birds became more apparent as the virus spread throughout the Mississippi Flyway and the Central Flyway to the west. In 2002 new modes of transmission between humans, through organ transplants, blood transfusions, and possibly nursing, became evident. The list of vertebrate hosts affected increased and included captive rocky mountain goats, sheep, reindeer, additional exotic bird species, and domestic pets. A large die-off of owls and hawks may have been caused by WNV.

Experimental studies of domestic and wild birds revealed that infections in poultry resulted in no clinical disease but produced some pathologic lesions, whereas clinical disease and $30-50 \%$ fatality occurred in domestic geese. Infected poultry circulated low amounts of virus in their blood (viremia), probably insufficient to infect mosquitoes, but viremias in young geese were high enough to transmit the virus to mosquitoes. Direct contact transmission between birds did occur with goslings but not with chickens or turkeys. Susceptibility to WNV infection and clinical disease varied widely among wild bird species tested. The American crow, which was suffering the highest natural mortality from WNV infections, was also the most susceptible to experimental infections. Nearly $100 \%$ mortality occurred within four to seven days following inoculation with a $1999 \mathrm{New}$ 
York strain of WVV virus, and direct transmission between infected birds and control birds in direct contact with each other occurred. Oral transmission of WVV from infected infant white mice to crows was demonstrated. Viremias in crows throughout the infection period were of high titers, making them competent reservoirs to ampiify transmission, despite their death from the infection. Other wild bird species showed similar but less severe responses and were also competent hosts for the virus, whereas some other species were unaffected by the virus, similar in response to domestic poultry. Killed-virus vaccines, including the conditionally licensed WNV equine vaccine, were partially successful in protecting crows from mortality from experimental WNV infection.

The large and rapid geographical expansion of WNV following its introduction into the continent in 1999 indicates how easily this virulent strain of virus became established, and suggests that it will likely continue to spread widely throughout the western hemisphere, following the movements of migratory bird populations. The western states and countries in Central and South America and the Caribbean may soon be faced with the public and animal health issues of this new arbovirus. In the US human infections with WNV are mostly subclinical and $20 \%$ develop mild disease. Less than $1 \%$ develop an age-related severe neurological disease, but with a 10 to $14 \%$ fatality rate. Less is known about subclinical infections in equines, but clinical disease has a rapid onset of staggering, ataxia, and muscle weakness with a 30 to $33 \%$ fatality rate. The public health significance for the LS has already nearly equaled or exceeded in 4 years the affect of SLE, western equine encephalitis (WEE), and eastern equine encephalitis (EEE) viruses on human illness for the last 40 vears. It has also far exceeded the impact of WEE and EEE on equine health during the last 40 years, even during 2002, in the historical endemic zone of WEE in the northern Great Plains states. The health impacts of WVV on human and equine populations in Latin America could be more severe because of underlying factors of lower nutrition, higher frequency of other diseases and health problems, less health care support, and more exposure to infected mosquitoes. The massive wild bird mortality associated with $\mathrm{WNV}$ is new for the arboviruses and is raising concern among avian biologists as a possible serious threat to the conservation of some migratory and non-migratory avian species. It is hoped that the virus activity will shift to an endemic form and that disease outcomes will become less severe.

The contributions of veterinarians to WNV are obvious and important, because this is a serious and emerging zoonotic disease of wildlife affecting domestic animal and human health over a broad region. Contributions are needed to treating and preventing clinical disease in equines and other animals; to diagnosis; to vaccine development, use, and evaluation; to surveillance; to epidemiology; to field and laboratory investigations of domestic animals and wildlife; and to studies on the pathogenesis of the virus.

\section{AUTHOR INFORMATION}

Robert G. Mclean, PhD, is the Research Program Manager for Wildiffe Diseases at the National Wildlife Research Center, WS/ APHIS/LSDA, Fort Collins, CO 80521. E-mail

Robert.G.McLean@aphis.usda.gov 